\title{
Upaya bimbingan konseling nilai dan spiritual terhadap Transgender di Yogyakarta Ardiansyah $^{1}$ \\ ${ }^{1}$ Pascasarjana UIN Sunan Kalijaga Yogyakarta ansyah_ardi2828@yahoo.co.id
}

\begin{abstract}
Abstrak
Melaui artikel ini penulis memberikan gambaran terkait pelaksanaan bimbingan konseling nilai dan spiritual terhadap transgender dalam menumbuhkan nilai dan spiritualnya untuk kehidupan kesehariannya serta berbagai upaya yang dilakukan oleh Konselor/pembimbing. Dalam penelitian ini bimbingan konseling nilai dan spiritual dapat dilihat sebagai jendela untuk membaca dan melihat lebih jauh fenomena bimbingan nilai dan spritualitas terhadap transgender yang dilakukan dengan berbagai upaya. Disamping itu, akan di fokuskan pada pokok permasalahan besar dengan rumusan masalah terkait proses bimbingan konseling nilai dan spiritual terhadap santri Pondok Pesantren Waria Al-Fatah Yogyakarta, serta faktor pendukung dan penghambat bimbingan nilai dan spiritual santri. Adapun metode penelitiannya yakni menggunakan penelitian kualitatif dengan mendeskripsikan terkait bimbingan konseling nilai dan spiritual santri. Dari hasil penelitian menunjukkan bahwa bimbingan yang dilakukan dalam meningkatkan spiritual santri yakni, bimbingan dan koseling pribadi-sosial serta bimbingan dan konseling religius. Adapun faktor pendukung dan penghambatnya yakni, adanya dorongan motivasi santri mendalami nilai spirtual melalui bimbingan nilai dan spritualitas. Adapun faktor penghambat yakni, kurangnya respon masyarakat publik serta respon lingkungan sekitar dengan adanya pengucilan di masyarakat. Ini dilakukan agar terpenuhinya bimbngan nilai dan spiritual transgender untuk belajar mengenal Islam melalui nilai dan spritual dalam kehidupannya.
\end{abstract}

Kata Kunci : Pelaksnaan bimbingan Konseling Nilai Spiritualitas

\begin{abstract}
Through this article provides an overview related to the implementation of counseling of value and spiritual counseling on transgender in fostering the value and spiritual for their daily lives as well as various efforts carried out by counselors. In this study, counseling on value and spiritual counseling can see further the phenomenon of guidance on values and spirituality towards transgender people. major issues with the formulation of the problem related to the process of counseling the value and spiritual counseling for the students of Waria al-Fatah Islamic Boarding School in Yogyakarta, as well as supporting factors and obstacles to the guidance of values and spiritual santri. The research method is using qualitative research by describing santri's spiritual and value counseling. From the results of the study indicate that the guidance is carried out in improving the spiritual of the students namely, personal-social guidance and counseling and religious guidance and counseling. As for the supporting and inhibiting factors, namely, the motivation for students to explore spiritual values through the guidance of values and spirituality. The inhibiting factors are the lack of response from the public and the response of the surrounding environment to the existence of isolation in the community.
\end{abstract}

Keywords: Counseling Guidance Implementation Values of Spirituality 



\section{PENDAHULUAN}

Diskusi terkait dengan transgender berawal dalam sejarah Islam yakni pada masa Khalifah pertama Abu Bakar al-Shiddiq. Pada saat itu homoseksual dibunuh bahkan dibakar secara hidup-hidup, sebab hal itu mengancam kekhalifaan pada waktu itu, serta menggangu ummat Islam pada masa itu. Kemudian berlanjut pada khalifah kedua, Umar bin Khattab yang mana homoseksual dirajam hingga wafat. Kemuadian berlanjut lagi pada masa Khalifah Ali Bin Abi Thalib, yakni homoseksual dihukum dan kemudian mereka dibuang sebab hal itu sama-sama mengancam kestabilan kepemimpinan waktu itu (Rabab, 2010, p. 467).

Sebenarnya keberadaan

Transgender atau biasa disebut dengan waria di Indonesia bukanlah hal yang baru, sebab waria atau homo seksual sudah banyak ditemukan dalam tradisi lokal dalam masyarakat. Hal tersebut ditandai dengan kegiatan seni, ritual kebatinan, ritus, perdukunan dalam masyarakat (Oetomo, 2013, p. 18). Keberadaan transgender saat ini tentunya menimbulkan banyak polemik, baik itu penentangan maupun penerimaan dalam lingkungan masyarakat. Seperti polemik transgender yang tergabung dalam kalangan Lebian, Gay, Biseksual, Dan Transgender (LGBT) ("Perluasan Pasal Zina dan
Kriminalisasi LGBT dalam RKUHP," 2018)

Di Indonesia perkiraan jumlah gay dan lesbian sekitar 800 ribu, hal tersebut perkiraan pada tahun 2009 dan diprediksikan akan terus meningkat dari tahun ke tahun (Khilman, 2015). Berdasar pada hasil penelitian tersebut tentunya juga dibutuhkan peran agama dalam memberikan bimbingan. Melihat hal tersebut, maka agama merupakan wahana penanaman pemahaman nilai-nilai spiritualitas dari manusia.

Agama dapat memperkenalkan manusia dengan tuhannya yaitu Allah, maka dengan begitu agama merupakan sarana untuk berhubungan dengan Allah yang dapat mengangkat derajatnya, membersihkan jiwanya dan mensucikan batinnya dan menjadikan mereka tidak menyimpang dari hakekat dan tujuan utama mereka diciptakan, maka sungguh itulah kesempurnaan manusia yang sejati (al-Ghazali, 2003, p. 101).

Pada dasarnya bahwa nilainilai pada diri manusia dapat dilihat dari tingkah-laku. Para filosof lebih tertarik untuk membedakan nilai, misalnya, membedakan nilai perilaku dalam konteks nilai antara (means values) dan nilai akhir (end values) (Kirschenbum, 1992:87). Sementara itu, Rokeach menggunakan istilah yang berbeda dalam menyebut nilai antaranya sebagai nilai instrumental dan nilai akhir sebagai nilai terminal. 
Namun,adapun nilai yang akan dikaji dalam tulisan ini adalah nilai pada tataran bimbingan spiritual, baik itu nilai yang dapat menimbulkan perilaku dekat dengan wilayah nilai etika (baik-buruk). Dalam perkembangannya terkadang nilai tak dapat dipisahkan karena nilai pada dasarnya adalah suatu keyakinan atau yang mana seseorang dapat bertindak atas dasar pilihannya.

Salah satunya dapat kita lihat pada nilai moral ini memiliki kualitas baik-buruk yang sudah dimanifestasikan dalam tindakan sebagai adat kebiasaan seseorang. Nilai moral ini diyakini dapat mendasari prinsip dan norma yang memandu sikap dan perilaku dalam hidup sebagai pembentukan karakter seseorang. Kualitas seseorang ditentukan oleh nilai yang dihayati dan digunakan sebagai pemandu sikap dan perilakunya.Watak atau karakter dan kepribadian seseorang dibentuk oleh nilai-nilai yang dipilih, diusahakan, dan secara konsisten diwujudkan dalam tindakan (Wening, 2012).

Adanya lembaga bimbingan konseling yang mengarahkan seseorang kepada spiritual amatlah diperlukan sebab, bimbingan dan konseling nilai dan spiritual diartikan sebagai proses pemberian bantuan kepada individu agar kembali pada fitrahnya sebagai manusia, mampu berperilaku sesuai dengan nilai-nilai yang diyakininya, hingga mampu menemukan solusi atas masalahnya. Dalam konseling spiritual intervensi yang ditekankan lebih pada poin ketuhanan dalam mengatasi masalah kehidupannya yang mengarah pada perbaikan diri agar menjadi lebih baik (A Hallen, 2005, p. 16).

Dalam hal ini, penulis akan melakukan penelitian pada lembaga pendidikan Pondok Pesantren non formal yang melakukan bimbingan konseling dalam menumbuhkan nilai dan spiritual kepada santri. Namun adapun yang menjadi studi dalam penelitian ini yakni Pondok Pesantren Waria Al-Fatah Yogyakarta di Kota Gede, yang merupakan sebuah lembaga pendidikan Pondok Pesantren non formal dengan melakukan bimbingan dan koseling nilai spiritual terhadap santri transgender atau biasa disebut waria, dengan lokasi yang berada di Kota Gede.

Keberadaan Pondok Pesantren ini tentunya dapat membantu santri khsusyna transgender dalam bimbingan konseling terhadap nilai dan spiritual santri. Dalam hal ini Pondok Pesantren Waria Al-Fatah juga berorientasi pada bimbingan dan konseling dalam menigkatkan nilai dan spiritual kepada santri transgender yang digagas dan membentuk sebuah kelompok belajar agama dalam lingkup Pondok Pesantren yang bertujuan dalam bimbingan nilai dan spiritual kepada transgender. 
Berbagai realitas mengenai adanya bimbingan konseling yang dilakukan dalam pelaksanaan bimbingan nilai dan spiritual kepada santri. Maka pokok yang dijadikan objek dalam penelitian ini, yakni dengan tujuan untuk mengetahui kontribusi serta fenomena bimbingan konseling nilai dan spiritual di kalangan transgender. Kemudian penulis akan menguraikan serta memfokuskan bagaimana bimbingan konseling nilai dan spiritual terhadap santri Pondok Pesantren Waria Al-Fatah yang berlokasi Kota Yoygakarta ?. Sub masalahnya adalah (1) Bagaimana langkah bimbingan dan konseling dalam meningkatkan nilai dan spiritual terhadap transgender ?, (2) Faktor-Faktor Apa yang mendukung dan menghambat bimbingan dan konseling nilai dan spritual terhadap transgender?.

\section{METODE PENELITIAN}

Penelitian ini dilakukan dengan studi lapangan atau disebut sebagai field research (Lawrence, 2003). Hal ini yang dilakukan di lembaga Pondok Pesantren Waria Al-Fatah Yogyakarta. Adapun penelitian yang digunakan adalah penelitian kuliatatif dengan penggambaran kondisi secara faktual dan nyata yang ada di lapangan dengan melakukan pengamatan dengan fenomena yang terjadi (Maleong, 1995, p. 11). Metode dan pendekatan yang digunakan yakni pendekatan bimbingan yang dilakukan oleh guru maupun pembimbing yang ada di lembaga pesantren tersebut agar mampu membimbing dalam meningkatkan nilai dan spiritual (Arifin, 1997, p. 20).

Data dalam penelitian ini bersumber dari pimpinan Pondok Pesantren, pembina agama/ustadz dan para santri yang ada di Pondok Pesantren. Dengan informan sebanyak empat orang meliputi, dua santri, satu pembimbing agama/ustadz dan pimpinan Pondok Pesantren yang masing-masing di Kota Gede Yogyakarta. Adapun metode pengumpulan data dalam penelitain ini dengan observasi, wawancara langsung, Focus Group Discusion (FGD) dan dokumentasi terkait data data yang ada dalam lingkup pesantren serta data tambahan dari informan santri dan data dari pembimbing agama/ustadz. Instrument yang diguanakan dalam penelitain ini yakni mengumpulkan informasi dari catatan, rekaman dan pedoman pertanyaan.

Pengolahan data $\begin{array}{r}\text { dalam } \\ \text { penelitian ini lebih } \\ \text { kepada }\end{array}$
pengolahan secara sistematis, berdasarkan hasil pengamatan yang ada di lembaga pendidikan pesantren yang dijadikan tempat penelitian di Kota Gede, Yogyakarta. Setelah data terkumpulkan maka akan dideskripsikan berdasar pada temuan yang ada di lapangan dan dijadikan laporan penelitian. Prosedur pengolahan data tersebut dilakukan 
secara analisis dan interaktif agar dapat menemukan hasil yang akurat.

\section{HASIL DAN PEMBAHASAN \\ 1. Gambaran Umum Pondok Pesantren Waria Al-Fatah Yogyakarta}

Adapun yang menjadi lokasi penelitian yakni Pondok Pesantren Waria Al-Fatah Yogyakarta. Lokasi penelitian ini terletak di Kota Gede Yogyakarta. Pondok Pesantren ini terletak di Kampung Notoyudan, Kelurahan Pringgokusuman, Godean Tegen, Yogyakarta. Pondok Pesantren ini awalnya didirikan oleh ibu Mariani pada tahun 2008 namun santrinya masih kurang, sehingga kembali beroprasi pada tahun 2014. ("Profil Pondok Pesantren Waria AlFatah Yogyakarta," 2018).

Setelah Ibu Mariani wafat, maka Pondok Pesantren ini dipindahkan ke Kota Gede Yogyakarta, yang kemuadian beralih kepada Ibu Shinta Ratri yang berlokasi di Celanan, Jagalan, Bagungtapan, Bantul Kota Gede Yogyakarta. Pondok pesantren ini yang dulunya disebut sebagai Pesantren waria dan kini beralih nama menjadi Pondok Pesantren Waria al-Fatah Yogyakarta Kota Gede dengan jadwal Pesantren Senin-Kamis.

Pondok Pesantren ini terletak dalam lingkup perkampungan warga dan mereka berada sekitar perkampungan dengan masyarakat setempat. Pondok Pesantren Waria Al-Fatah Yogyakarta, merupakan sebuah pondok pesantren yang tekesan tidak terlalu formal seperti Pondok Pesantren yang pada umunya, namun memiliki santri dari kalangan transgender atau sering disebut waria.

Hal ini dapat kita lihat dengan jadwal belajar yang disesuaikan dengan hari libur atau dengan istilah. Pondok Pesantren ini tidak begitu banyak membina santri, sebab jumlah santri pondok pesantren hanya berjumlah 42 orang. Waktu belajar mereka di mulai pada hari minggu sore pukul 16.00-21.00 malam yang diisi dengan kajian keagamaan.

Pada awalnya pendirian Pesantren ini bermula ketika tidak adanya penerimaan masyarakat kepada kalangan transgender yang ingin belajar agama dan menumbuhkan nilai dan spritaul keberagamaanya, sehingga ia merasa tersingkirkan dan masyarakat tidak mau menerimah keberadaanya. Sejalan dengan hal itu juga diungkapkan oleh Taslim mengatakan:

"Kami dianggap sebagai masalah komunitas yang melawan kodrat Tuhan dengan fisik dan kelakuan kami, kami sendiri mengangap itu sebagai takdir. Sebab andai saya ingin disuruh memilih maka saya memilih sebagai seorang pria atau wanita dan bukan waria. Sebenarnya kami tidak ingin seperti ini dan ingin kembali kepada kodrat kami sebagai mahluk 
bertuhan dengan menumbuhkan nilai dan spritualnya dalam beragama dengan benar, ingin berbaur dengan masyarakat luas dan ingin mendapat perlakuan yang sama baik di masyarakat maupun pemerintah."'(Taslim, 2018).

Para santri yang ada di Pondok tersebut berasal dari berbagai kalangan profesi pekerjaan serta daerah yang berbeda. Sebagian dari mereka ada yang tinggal dalam lokasi Pondok dan sebagian juga ada yang hanya sekedar datang belajar pada hari minggu. Orientasi penerimaan santri di Pondok Pesantren Waria Al-Fatah ini dengan merekrut anggota santri dari kalangan transgender yang ada di Yogyakarta yang ingin belajar agama dalam menumbuhkan nilai-nilai spiritual kaum waria. Rentan usia santri yang ada di Pondok Pesantren ini yakni usia 24-50 tahun dari berbagai profesi pekerjaaan lainnya.

\section{Langkah Bimbingan dan Konseling dalam Meningkatkan Nilai dan Spritual \\ Transgender (waria)}

Pada umumnya spiritualitas merupakan identitas fundamental individu yang merupakan puncak capaian perkembangan dimana individu mampu mencari makna tujuan dan hakikat hidup. Sebab spiritualitas yang dimiliki oleh individu bisa mencegah timbulnya perilaku tercela, sehingga mampu hidup dengan mental yang sehat. Spiritualitas bukan hanya sebagai integral dan signifikan dalam pengalaman individu, tetapi hal itu merupakan bagian dari perkembangan individu. Adanya pemisahan dan pengabaian terhadap aspek spiritualitas dalam kehidupan merupakan tindakan memisahkan bagian fundamental dalam identitas dan kehidupan individu (Imaduddin, 2017, p. 2).

Sejalan dengan hal itu, dari pendefenisian spritualitas dapat kita pahami bahwa spritualitas adalah sebuah upaya perkembangan dalam mencapai makna dan tujuan hidup yang mereka inginkan dalam kehidupannya. Spritualitas dalam pencapaiannya tentunya membutuhkan sinergi dengan bimbingan dan konseling agar dapat diarahkan menuju tujuan pencapaian spritualitas. Adanya bimbingan dan konseling dalam mencapai spiritual seseorang tentunya membutuhkan usaha dan sinergitas agar mampu mencapai perkembangan individu dengan adanya kontrol prilaku yang bisa merugikan diri sendiri, sehingga tercapai tujuan hidup yang mampu mengintegrasikan dalam nilai-nilai kehidupan.

Tak terlepas dari pelaksanaan nilai dan spiritual dalam bimbingan konseling, tentu hal itu tak dapat pula terpisahkan dari aspek aqidah serta aspek ubudiyah (Zulkarnain, 2008, pp. 27-28). Sebab aspek aqidah mencoba mengaktualisasikan 
potensi ketauhidan yang dimiliki oleh seseorang, bahkan telah di awali seorang hamba semenjak belum dilahirkan yaitu pada masa-masa di alam arwah, sebagaimana dalam QS: al-A'raf : 172. Keterkaitan nilai spiritual dalam aspek aqidah, juga terdapat nilai spiritual dalam aspek ibadah (ubudiyah). Ibadah yang dimaksud yakni pelaksanaan ritual ibadah seperti yang telah menjadi perintah dalam ajaran agama (alGhazali, 2003, p. 28).

Secara subtansial aspek nilai dan spiritual dalam hal aqidah dapat memberikan dua keuntungan besar bagi siapa saja yang melaksanakan ibadah sebagai ritual pengabdiannya kepada Allah swt. Keuntungan tersebut yakni, keuntungan ukhrawi dan keuntungan dunia. Adapun proses bimbingan spiritual yang dilakukan Pondok Pesantren agar dapat mengarahkan santri dalam meningkatkan serta menumbuhkan nilai dan spritual, maka ada beberapa langkah yang ditempuh oleh Pondok Pesantren Waria Al-Fatah dalam melakukan upaya pembinaan dengan bimbingan dan konseling nilai dan spritual yakni :

\section{a.Bimbingan Konseling Pribadi-} Sosial Santri Transgender

Pelaksanaan bimbingan konseling pribadi dan sosial di kalangan transgender yang ada di Pondok Pesantren ini tentunya menjadi sebuah kebutuhan yang amat urgen bagi kalangan transgender. Sebab secara manusiawi kalangan transgender adalah merupakan mahluk sosial yang membutuhkan interaksi dan komunikasi serta pemenuhan spritual dalam kehidupannya, sebagaimana pada masyarakat umumnya yang membutuhkan akan hal itu. Namun terkadang hal itu tidaklah mudah bagi kalangan transgender yang ada di Pondok Pesantren Waria Al-Fatah Yogyakarta.

Adanya kecaman dan stigma negatif yang harus diterimah oleh kalangan transgender sehingga merasa tersingkirkan dalam lapisan sosial masyarakat. Melihat fenomena ini maka bimbingan konseling pribadi dan sosial yang dilakukan konselor dalam hal ini pembimbing agama dan pimpinan Pondok Pesantren Al-Fatah yakni dengan memberikan layanan konsultasi sosial maupun layanan konsultasi pribadi kepada klien dalam hal ini santri, untuk memberikan dukungan sosial dan empati yang diberikan dalam penyesuaian diri santri.

Bentuk pemberian layanan bimbingan konseling konsultasi pribadi - sosial ini, para konselor dalam hal ini pembimbing dan Pembina memberikan pemahaman dan penyadaran diri kepada santri terkait dia sebagai mahluk sosial dan mahluk Tuhan. Pada dasarnya pelaksanaan konseling pribadisosial ini dapat kita mengacu pada pendekatan Person-centered 
dengan pemberian bantuan pengungkapan perasaannya yang dialami (Marianne H Mitchell, 2010, p. 126). Selain itu juga konselor atau Pembina pondok pesantren juga banyak mengaplikasikan layanan konseling dengan teknik Gestalt agar para klien atau santri dapat mengembangkan kesadaran mereka akan betapa ambivalen atau bertentangan serta rancunya mereka dalam kehidupan, sehingga konselor mengarahkan mereka akan pemenuhan hal itu.

Sebenarnya bila dikaitkan Pengaplikasian bimbingan konseling pribadi-sosial dengan hubungan kepada sesama manusia dan hubungan kepada Tuhan dalam bimbingan nilai dan spiritual ini, dapat mengantarkan seseorang dalam menjalangkan syariat Islam serta menjaga hubungannya kepada sesama manusia dalam bersosialisasi. Hal tersebut bisa diwujudkan melalui etika dan nilai yang dimiliki seseorang dalam memanusiakan manusia serta menjalin keakraban terhadap sesama dan juga mengedepankan nilai-nilai kebaikan dalam hidupnya.

Semua hal ini dapatlah tercapai jika seseorang baik itu dalam lingkungan sekolah, masyarakat serta komunitas yang mampu mengintegrasikan peranan bimbingan pribadi-sosial dengan nilai dan spiritual dalam hidup seseorang agar menjadi manusia yang memiliki banyak manfaat serta menebar kebaikan dalam hidupnya.

Sehubungan apa yang di sampaikan oleh Arif selaku pembimbing, ia mengungkapkan bahwa dalam proses pelaksanann bimbingan nilai dan spritualitas selalu menggunakan layanan bimbingan konseling pribadisosial santri yang lebih menekankan pada pemenuhan nilai spritualitas santri dengan mencerminkan ahlak dalam pribadi santri transgender serta hubungan sosial kepada masyarakat dalam berinteraksi, agar ia dapat kembali berdaptasi dan menyesuaikan diri dengan lingkungan serta dengan harapan masyarakat luas dapat menerimah dan memberikan perlakuan, pembinaan dan pendampingan kepada transgender dalam bersosialisasi diruang publik.

Namun terkadang waria yang sudah berkomitmen untuk berubah, namun sering mendapat perlakuan yang tidak mengenakkan dalam masyarakat, baik itu berupa pengucilan maupun tidak menerimahnya dalam lingkungan masyarakat. Namun tetap memberikan bimbingan konselig pribadi-sosial dengan dukungan motivasi dan empati kepada santri terkait dengan langkah yang ditempuh untuk pencapaian jati diri dengan 
bimbingan nilai dan spiritual dalam berinteraksi dan sebagai mahluk beragama."(Arif, 2018)

Berbagai penjelasan di atas maka telah terdeskripsikan aplikasi dari layanan konseling ini, maka penulis berkesimpulan bahwa pelaksanaan bimbingan konseling pribadi-sosial ini amatlah memiliki urgensi khususnya bagi kalangan transgender yang membutuhkan bimbingan pribadi-sosial melalui wadah konseling secara induvidu dengan menggali dan membantu permasalahan penyesuaian diri, baik terhadap penyesuaian dalam dirinya sendiri sebagai mahluk Tuhan yang membutuhkan ketenangan jiwa dengan peningkatan spritualitas, maupun penyesuaian dalam lingkungan sosial masyarakat terutama keluarga. Karna keluarga sendiri terkadang kurang memberi dukungan dalam penyesuaian diri secara sosial maupun pemenuhan nilai dan spiritual.

b. Bimbingan dan Konseling Religius Satri Transgender

Pada dasarnya bimbingan dan konseling religius memilki atri penting dalam menetapkan atau memposisikan klien sebagai mahluk Tuhan dengan seperangkat kemuliaan yang dimiliki dan menjadi tujuan dalam bimbingan konseling. Dapat juga kita pahami bahwa bimbingan dan konseling religius yakni suatu pemberian bantuan kepada individu yang mengalami kesulitan secara rohania dan batiniah yang berkaitan dengan spritualitas yang dirahkan kepada pemberian bantuan kepada diri sendiri melalui kekuatan iman serta taqwa dengan segala potensi yang dimiliki.

Melihat realitas layanan tersebut maka hal inilah yang juga ikut di kontekstualisasikan oleh Pondok Pesantren Waria Al-Fatah Yogyakarta dengan melakukan bimbingan konseling religius dengan peningktanan nilai dan spritualitas. Sesungguhnya cara pandang psikologis terhadap manusia, memandang bahwa manusia pasti akan mengalami proses pertumbuhan dan berkembangan. Begitupun dengan nilai spiritual dalam diri manusia yang bisa mengalami perkembang sejalan dengan pertumbuhan individu tersebut. Salah satu cara yang bisa digunakan agar dapat dilakukan dalam memunculkan nilai spiritual individu selain dengan bentuk ibadah, ialah melakukan proses konseling. Sebab spiritualitas bisa dalam konteks pendidikan dan spiritual merupakan bagian dari perkembangan manusia (Imaduddin, 2017, p. 2).

Selain itu, Elfi Mu'awanah dan Rifa Hidayah (Mu'awanah \& Hidayah, 2009, pp. 151-152). 
Dalam

$$
\text { penelitiannya }
$$

menyebutkan bahwa adanya

kecenderungan klien untuk

melakukan konseling terhadap orang yang memilki keyakinan agama yang kuat, serta dijadikannya pijakan agama sebagai dasar dalam pelaksanaan konseling terhadap klien. Pada pelaksanaan konseling juga diperlukan adanya pemberian pemahaman nilai yang kuat terhadap klien dengan pengintegrasian unsur agama di dalamnya.

Hal ini yang menjadi dasar pijakan seorang konselor dalam hal ini, pembimbing agama dalam melakukan bimbingan konseling religius dalam peningkatan nilai dan spiritual di Pondok Pesantren Waria Al-Fatah Yogyakarta. Pada pelaksanaan bimbingan konseling religius terhadap peningkatan nilai spiritual ini, para klien dalam hal ini santri begitu aktif mengikuti kegiatan konseling dan kajian rutin yang diberikan konselor atau pembimbing agama dengan bertemu langsung di Pondok Pesantren.

Bukan hanya mengikuti pengajian semata, namun konselor berupaya membangun aspek nilai dan spiritual santri melalui kajian keagamaan kepada santri transgender terkait materi penguatan aqidah serta aspek peningkatan nilai spritualitas santri yang berikan oleh para konselor dala hal ini ustadz/pembimbing dengan berbagai latar belakang keilmuan keagamaan yang memumpuni.

Sebab materi bimbingan konseling religius yang disajikan selalu bervariasi, baik itu materi aqidah, fiqih, mauamalah, kajian tafsir materi tematik serta layanan konsultasi agama. Disamping itu pula konselor banyak memberikan asumsi dan penguatan secara lahiria dan batiniah dengan konsultasi secara langsung kepada santri transgender terkait polemik dirinya yang terkadang kurang percaya diri, sehingga konselor membangun hal itu melalui konseling religius untuk menigkatkan nilai dan spiritual santri. Adapun semua bimbingan dan konseling yang dilaksanakan ini bermuara kepada bimbingan dalam menumbuhkan nilai spiritual kepada santri.

Seperti yang di ungkapkan Ibu Shinta Ratri bahwa pelaksanaan bimbingan dan konseling religius terhadap penigkatan nilai dan spiritual yang dilakukan di pondok pesantren, ialah agar dapat meningkatkan pemahaman agama bagi kalangan transgender, serta pemenuhan dan penigkatan nilai dan spritualitas santri dalam mengarungi kehidupan seharihari.

Dengan terlaksananya bimbinagn religius ini diharapkan 
mampu membangun hubungan baik kepada sesama manusia, maupun hubungan kepada Allah melalui bimbingan nilai dan spiritual.

Pada pelaksanaan ibadah kalangan transgender, konselor/pembimbing tidak banyak memberikan pemaksaan untuk melaksanakan kegiatan ibadah, melainkan konselor berusaha sedikit demi sedikit dapat mengarahkan dan pemberian sugesti positif kepada santri untuk mengamalkan ajaran agama melalui konseling religius untuk menigkatkan nilai dan spiritual santri. Hal ini tidak begitu dipaksakan sebab tergantung dari sebagaimana mereka merasa nyaman dan telah menemukan jati dirinya dalam beragama dalam pemenuhan nilai dan spiritualnya.“(Shinta Ratri, 2018).

Pada dasarnya adanya naluri ketuhanan transgender dalam mengekspresikan ketuhanannya melalui peningkatan nilai dan spritualitasnya, tentunya menjadi dasar bagi transgender untuk menjalangkan dan mengaplikasikan

penghambaannya sebagai seorang mahluk ciptaan Tuhan. Dorongan naluri ketuhanan yang ada dalam diri transgender mengantarkan akan pencarian jati diri, serta sebagai perjalanan spritualitasnya dalam mengenal agama.
(Khilman, 2015) dalam penelitanya yang merilis kajian Counseling and Mental Health Care of Transgender Adult and Loved One (2006) fenomena transgender muncul tidak hanya karena pengaruh lingkungan. Namun dalam sudut pandang ilmu kesehatan mental, transgender bisa muncul dipengaruhi oleh budaya, fisik, seks, psikososial, agama dan aspek kesehatan. Muculnya fenomena transgender dalam melaksanakan bimbingan nilai dan spiritual tentu halnya tidak bisa sepenuhnya untuk dipaksakan dalam beribadah, utamanya dalam hal pemilihan pakaian, sebab ia masih mencari jati diri dan dalam proses penyesuaian diri dalam lingkungan maupun masyarakat.

Dalam pelaksanaan konseling, khususnya kepada klien, tentuya dibutuhkan konselor yang melakukan konseling secara Islami dengan pemberian bantuan kepada santri agar mampu menyadari fitrahnya sebagai makhluk beragama dan sejalan terhadap ketentuan dan petunjuk Allah. Untuk menciptakan kondisi demikian, maka tentunya dibutuhkan adanya pelayanan konseling Islami dalam melakukan bimbingan nilai dan spritual terhadap klien yakni, Pertama berpedoman kepada wahyu serta ketauladanan para Nabi, sebab dalam psikologi 
Islam mengakui wahyu sebagai sumber kebenaran yang hakiki. Kedua, kewajiban seorang konselor dalam hal ini memberikan layanan konseling kepada klien merupakan sebagai kewajiban, Ketiga, apabila seorang konselor atau pembimbing melakukan perbuatan yang tercela, maka hal itu dapat berakibat fatal. Sebab tugas utama sebagai seorang konselor adalah untuk mengarahkan klien kepada ketaatan kepada Tuhan serta pemberian bantaun kepada klien (Nuraini, 2017, p. 8).

Meskipun secara eksplisit, alQur'an menyebut dua jenis identitas seks laki-laki dan perempuan, namun literatur ilmu fiqih ada empat varian, yaitu: perempuan, laki-laki, khunsa (waria atau banci, atau seseorang yang memiliki alat kelamin ganda yang disebut dengan khunsa musykil), dan munkhannis (lakilaki secara biologis, namun mengidentifikasi diri sebagai perempuan dan menginginkan pergantian kelamin) atau mukhannas (secara biologis lakilaki tetapi tidak berkeinginan mengubah jenis kelamin mereka.) (Mulia, 2010, p. 292). Dengan adanya pembagian jenis kelamin dalam ajaran Islam ini, tentunya merupakan sebuah tantanagan bagi para konselor/pembimbing dalam menuntun para transgender, agar ia kembali kepada jalan yang benar dan sesuai dengan ajaran Islam dan dapat menerimah kodrat dan ketetapan Tuhan baik itu laki-laki maupun perempuan.

Peningkatan nilai dan spiritual melalui bimbingan dan konselong religius ini, tentunya juga mendapat respon positif dari para santri. Salah satunya Ruli mengungkapkan bahwa :

"Keberadaan pengajian rutin dapat membantu kami para waria untuk mampu menamkan nilai dan spiritual dalam dirinya, terutama nilai-nilai akhlak dalam berperilaku serta untuk mencari dan menemukan jati dirinya sebagai seorang hamba kepada Tuhan. Terkadang sering tersingkirkan dan tidak ada nya pengakuan keberadaan kami, sehingga memutuskan untuk belajar agama di pondok pesantren yang menjadi sebuah wadah para kaum transgender untuk menemukan nilai dan spirutual dalam dirinya."(Ruli, 2018).

Berbagai pamaparan argumen di atas, maka dapat kita menarik kesimpulan bahwa bimbingan dan konseling religius dalam menigkatkan nilai spiritual santri adalah upaya pemberian bantuan kepada klien untuk mengarahkan mereka mendapatkan makna kehidupannya melalui bimbingan yang diberikan dalam pelaksanaan konseling untuk meningkatkan 
spiritualitas. Selain itu bimbingan konseling spiritualitas memiliki peranan penting dalam mengarahkan seseorang untuk mencapai tujuan pada puncak kebahagiaan dengan pendekatan spiritual, selain itu agar mampu mengintegrasikan nilai-nilai positif dalam kehidupannya.

Dengan adanya berbagai latar belakang kultur dan bahasa dari berbagai santri transgender membuka wawasan berfikir kita, bahwa dengan adanya keterbatasan ruang berekspresi dan beribadah kepada kalangan transgender tidak menyulitkan mereka dalam peningkatan nilai dan spritualnya melalui bimbingan konseling religius yang dilaksanakan di Pondok Pesantren terhadap kalangan transgender.

3. Faktor yang Mendukung dan Menghambat Bimbingan dan Konseling Nilai dan Spiritual Transgender (waria)

a. Faktor yang Mendukung Dalam Bimbingan Konseling Nilai dan Spiritual Santri

Dalam melakukan bimbingan nilai dan spiritual, maka tak luput juga dari faktor pendukung, salah satunya adanya keinginan para waria untuk belajar agama. Meski hal itu amat sulit baginya sebab begitu banyak tekanan dari masyarakat, namun hal itu tak menurunkan semangat para santri untuk belajar agama. Hal ini dilakukan agar membangun moral dan prilaku serta bisa mengikuti norma yang ada di masyarakat. Hal ini diungkapkan oleh Ibu Shinta Ratri bahwa :

"Antusias santri untuk belajar agama agar bisa menigkatkan nilai dan spiritualitasnya dengan harapan ia bisa merubah perilakunya, kembali dalam keluarganya serta mengarahkan dirinya kepada penguasaan diri dengan nilai dan karakter dengan memenuhi tanggung jawabnya sebagai sebagai hamba dan sebagai warga Negara."(Ratri, 2018).

Walaupun untuk kembali kedalam lingkungan masyarakat setelah mereka mulai berubah dan kembali melakukan ajaran agama melalui bimbingan nilai dan spiritualitasnya, maka hal itu tidaklah muda dilakukan para waria. Sebab ia akan berusaha tetap menjalin komunikasi dalam masyarakat agar dapat diakui sebagai mahluk soaial dan tak terpinggirkan dalam lingkungan masyarakat. Pada pembinaan santri ini juga banyak di dukung oleh antusias para santri, salah satunya Taslim ia mengungkapkan bahwa :

"Sangat merespon baik dengan kehadiran pembinaan nilai dan spiritual yang dibentuk dalam satu kelomok belajar agama berupa pondok pesantren. Sebab selain ia diarahkan 
kepada

agama,(Taslim, 2018).

Meskipun dalam hal ini pemerintah secara kelambagaan melalui dinas terkait tetap merespon postif kegiatan pembinaan nilai dan spiritual yang dilakukan terhadap para santri. Hal ini dibuktikan dengan adanya perlakuan yang sama yang diberikan kepada kaum waria, baik itu dalam aspek kesehatan, pemerintahan maupun kegiatan keagaamaan.

\section{b. Faktor Penghambat Bimbingan} Nilai dan Spiritual

Untuk mewujudkan santri yang memiliki nilai dan spiritual melului perilaku dan perbuatan yang mencerminkan kebaikan dan menjalangkan perintah agama. Maka tentunya tak terlepaskan dari faktor keterbukaan masyarakat dalam menerimah keberadaan santri waria yang telah merubah hidupnya dengan banyak belajar agama. Sebab hal ini di ungkapkan oleh Ibu Shinta Ratri bahwa ;

"Terkadang santri yang telah keluar dari pondok pesantren ini, sebagian masyarakat terkadang belum bisa menerimah sepenuhnya keberadaan waria, baik itu dalam berinteraksi maupun dalam hal pelaksanaan ibadah dalam ruang publik. Kami Berharap masyarakat dapat menerimah baik itu keluarga dan mengakui keberadaan mereka. "(Ratri, 2018).
Hambatan dan kritik keras kepada waria yang telah belajar agama, terkadang masih sering dikucilkan dalam masyarakat. Hal ini tentu membutuhkan perlakuan hak yang sama sebagai seorang warga Negara yang memiliki hak dan kewajiaban untuk menjalangkan agamanya serta dapat berekspresi dalam ruang publik. Hal Ini disampaikan oleh Ibu Ruli, ia berharap pemerintah dan masyarakat dapat menerimah, serta tetap berpihak kepada transgender, juga menerimah keberadaan mereka yang telah kembali ke jalan yang benar dengan mengubah perilakunya dengan bekal bimbingan nilai dan spiritual terhadap santri, agar ia tetap bisa menjalangakan aktifitas ibadahnya dalam masyarakat (Ruli, 2018). Shinta Ratri juga menambahkan bahwa :

"Terkadang pelaksanaan ibadah mereka sering dicerca oleh masyarakat terkait ibadah yang mereka lakukan di ruang publik. Meskipun hal itu benar namun masyarakat tetap menolak serta dalam hal pelaksanaan ibadah mereka seringkali tidak nyaman."(Ratri, 2018).

Adanya keinginan untuk dapat diterimah dalam lingkungan masyarakat, khususnya keluarga tentunya mendapat hambatan. Sejalan dengan apa yang diungkapkan bahwa bagi mereka, keluarga benar-benar menjadi 
dasar atau fondasi harapan hidup mereka. Karena transgender pada dasarnya sudah mengalami konflik batin sejak ia merasakan keanehan atau situasi yang berbeda dengan orang lain. Hanya saja, ketika mereka memberanikan diri untuk menyatakan konflik batin dan identitas mereka secara terbuka, ternyata yang mereka dapatkan biasanya adalah cemoohan dan penolakan keras (Safri, 2016).

Berbagai relitas tersebut Pondok Pesantren Waria Al-Fatah Yogyakarta, mengalami begitu banyak hambatan yang dilalui dalam melaksanakan bimbingan nilai dan spritual. Hal ini tak menurunkan niat dan semangat para transgender untuk belajar agama, meskipun ia terpinggirkan oleh masyarakat luas terkait pelaksanaan ibadah mereka.

Dalam hal ini, mereka terkadang mendapat perlakuan yang kurang adil dalam masyarakat dalam hal belajar agama, sehingga mereka membentuk sebuah kelompok belajar tersendiri agar bisa belajar agama dengan asumsi adanya bimbingan spiritual agar mereka bisa hidup dan beribadah sesuai perintah ajaran agama. Adanya pendukung dan penghambat dalam melakukan bimbingan nilai dan spritual tentunya tak dapat dielakkan, sehingga hal ini dibutuhakn kesabaran dan

dukungan masyarakat untuk
mampu menyeimbangi dalam
melakukan bimbingan nilai dan
spiritual utamanya kalangan
transgender.

\section{SIMPULAN}

Pelaksanaan bimbingan nilai dan spiritual kepada santri Pondok Pesantren waria Al-Fatah Yogyakarta, merupakan upaya untuk menamamkan nilai-nilai dan spiritual dalam diri para santri agar mampu menjalangkan perintah agama dan memiliki hubungan yang baik antar sesama. Serta hubungan kepada sang- pencipta melalui akhlak dan perbuatan yang bernilai kebaikan dalam masyarakat dengan menjalangkan pengaplikasian ibadah kepada sesama manusia dan kepada Tuhan melalui upaya bimbingan dan konseling religius.

Adapun upaya yang dilakukan dalam bimbingan nilai dan spiritual yakni, melalui bimbingan dan konseling pribadi-sosial dan bimbingan konseling religius untuk pemenuhan nilai spritual yang diberikan oleh pondok pesantren dalam hal ini konselor atau pembina terhadap transgender. Upaya bimbingan ini memiliki tujuan agar para santri dapat menumbuhkan nilai dan spritualnya. Namun tak luput dari hal itu, bimbingan nilai spiritual ini bermuarah pada pemberian pemahaman keagamaaan santri agar kembali dalam lingkup masyarakat serta mampu di terimah 
keberadaanya dalam lingkungan masyarakat.

Faktor pendukung dan penghambatnya yakni, adanya dorongan dan motivasi dari para pembimbing dan santri waria di Pondok Pesantren, hal ini membuat semangat mereka tak pernah surut dalam belajar agama, meskipun mereka membetuk kelompok tersendiri dalam belajar agama. Namun langkah mereka tak luput juga dari beberapa faktor yang mendukung dan menghambat mereka dalam belajar agama, serta bimbingan nilai dan spiritual. Semua ini bertujuan agar para santri mampu merubah pola perilaku dan kembali menjalangkan kewajibannya sebagai hamba serta berinteraksi dalam masyarakat dengan tetap mengedepankan nilai dan norma masyarakat yang mampu bernilai positif serta bernilai ibadah dalam kehidupan.

Penulisan artikel yang di paparkan dalam tulisan ini tentunya menjadi sebuah kontribusi keilmuan para insan akademis dalam mengkaji tentang bimbingan konseling dalam menumbuhkan nilai dan sritual transgender. Kemudian diharapkan kepada peneliti selanjutnya untuk melanjutkan penelitian terkait dengan bimbingan konseling terhadap transgender dalam membangun aspek nilai spritualnya dalam masyarakat, yang memiliki kontribusi agar dapat merubah paradigma negatif masyarakat terkait dengan transgender yang seringkali dikucilkan dalam masyarakat.

\section{DAFTAR PUSTAKA}

A Hallen. (2005). Bimbingan dan Konseling. Jakarta: Quantum Teaching.

Al-Ghazali, M. (2003). Selalu Melibatkan Allah, Sehat Spiritual dan Sukses Sosial Jakarta: PT. Serambi Ilmu Semesta.

Arif. (2018, May 6). Wawancara Dengan Arif, Pendamping/Pengisi Kajian Rutin Pondok Pesantren Waria Al-Fatah Yogyakarta.

Arifin, M. (1997). Pokok- Pokok Pikiran Tentang Bimbingan dan Penyuluhan Islam. Jakarta: Bulan Bintang.

Imaduddin, A. (2017). Spiritualitas Dalam Konteks Konseling. Journal of Innovative Counseling: Theory, Practice \& Research, 1(1).

Khilman, R. A. (2015). "Enam Kontinum dalam Konseling Transgender Sebagai Alternatif Solusi Untuk Konseli LGBT." Jurnal Psikologi Pendidikan \& Konseling Universitas Negeri Makassar, 1(1), 50 57.

Lawrence, N., W. (2003). Social Research Methods: Qualitative and Quantitive 
Approaches. Boston: Ally and Bacon fifith edition.

Maleong, L. J. (1995). Metodologi Penelitian Kualitatif. Bandung: Remaja Rosdaya Karya.

Marianne H Mitchell. (2010). Bimbingan dan konseling. Yogyakarta: Pustaka Pelajar. Mu'awanah, E., \& Hidayah, R. (2009). Bimbingan Konseling Islami di Sekolah Dasar. Jakarta: Bumi Aksara.

Mulia, M. (2010). Islam dan Hak Asasi Manusia, Konsep dan Implementasi. Yogyakarta: Naufan Pustaka.

Nuraini, H. (2017). Strategi Spiritual Dalam Konseling Islam Pengintegrasian Konseling Kontemporer Dengan Konseling Islam. Presented at the (International Conference "Islamic University: Distinctions and Contributions,

Oetomo. (2013). Hidup sebagai LGBT di Asia: Laporan Nasional Indonesia. Indonesia: USAID dan UNDP.

Perluasan Pasal Zina dan Kriminalisasi LGBT dalam RKUHP. (2018, January 23). [https://nasional.kompas.com/ $\mathrm{read} / 2018 / 01 / 23 / 08121031 / \mathrm{pe}$ rluasan-pasal-zina-dan kriminalisasi-lgbt-dalamrkuhp.]. Retrieved May 8, 2018, from Profil Pondok
Pesantren Waria Al-Fatah Yogyakarta. (2018).

Rabab, A. (2010). Sexualities and the Social Order in Arab and Muslim Communities. Dalam Samar Habib. Islam and Homosexuality. ABC-CLIO.

Ratri, S. (2018, May 6). Wawancara Dengan Pimpinan Pondok Pesantren Waria Al-Fatah Yogyakarta.

Ruli. (2018, April 20). Wawancara Dengan Santri Pondok Pesantren Waria Al-Fatah Yogyakarta.

Safri, A. N. (2016). Penerimaan Keluarga Terhadap Waria atau Transgender (Studi Kasus Atas

Waria/Transgender Di Pesantren Waria Al-Fatah Yogyakarta). Jurnal Nizham, 5(1), 26-41.

Shinta Ratri. (2018, April 20). Wawancara Penelitian Pimpinan Pondok Pesantren Waria Al-Fatah Yogyakarta.

Taslim. (2018, May 6). Wawancara Santri Pondok Pesantren Waria Al-Fatah Yogyakarta.

Wening, S. (2012). Pembentukan Karakter Bangsa Melalui Pendidikan Nilai. Jurnal Pendidikan Karakter, 2(2).

Zulkarnain. (2008). Transformasi Nilai-Nilai Pendidikan islam. Yogyakarta: Pustaka Pelajar. 
